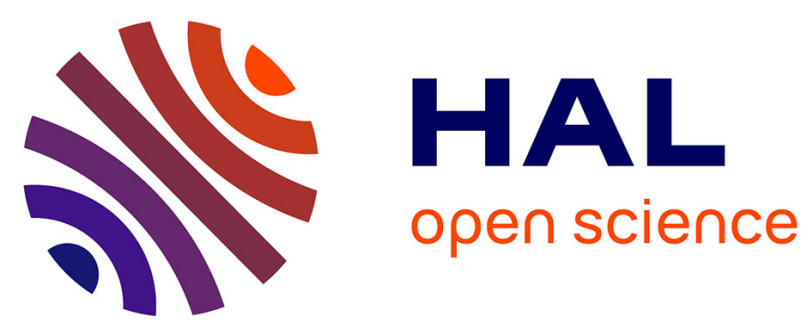

\title{
Comparison of microcalorimetry and haze formation to quantify the association of B-type procyanidins to poly-L-proline and bovine serum albumin
}

\author{
Aude Watrelot, Catherine M.G.C. Renard, Carine Le Bourvellec
}

\section{- To cite this version:}

Aude Watrelot, Catherine M.G.C. Renard, Carine Le Bourvellec. Comparison of microcalorimetry and haze formation to quantify the association of B-type procyanidins to poly-L-proline and bovine serum albumin. LWT - Food Science and Technology, 2015, 63, pp.376-382. 10.1016/j.lwt.2015.03.064 . hal-02636719

\section{HAL Id: hal-02636719 \\ https://hal.inrae.fr/hal-02636719}

Submitted on 27 May 2020

HAL is a multi-disciplinary open access archive for the deposit and dissemination of scientific research documents, whether they are published or not. The documents may come from teaching and research institutions in France or abroad, or from public or private research centers.
L'archive ouverte pluridisciplinaire HAL, est destinée au dépôt et à la diffusion de documents scientifiques de niveau recherche, publiés ou non, émanant des établissements d'enseignement et de recherche français ou étrangers, des laboratoires publics ou privés. 


\title{
Comparison of microcalorimetry and haze formation to quantify the association of B-type procyanidins to poly-L-proline and bovine serum albumin
}

\author{
Aude A. Watrelot ${ }^{\text {a, b, * }}$, Catherine M.G.C. Renard ${ }^{\mathrm{a}, \mathrm{b}}$, Carine Le Bourvellec ${ }^{\mathrm{a}, \mathrm{b}}$ \\ a INRA, UMR408 Sécurité et Qualité des Produits d'Origine Végétale, F-84000, Avignon, France \\ ${ }^{\mathrm{b}}$ Université d'Avignon et des Pays du Vaucluse, UMR408 Sécurité et Qualité des Produits d'Origine Végétale, F-84000, Avignon, France
}

Keywords:

Polyphenol

Protein

Affinity

Precipitate

ITC

\begin{abstract}
A B S T R A C T
Though many different methods have been applied to protein-tannin interactions, divergent results are often reported. To better understand the origin of these differences, we compare here haze/aggregates formation and thermodynamic parameters occurring for protein-procyanidin interactions. Proteins well referenced for interaction with polyphenols, namely a polypeptide of extended structure that resembles salivary proteins (poly-L-proline (PLP) and a standard globular protein (bovine serum albumin (BSA)) were used. Flavan-3-ols of three degrees of polymerization were tested, (-)-epicatechin (EPI), a dimer (DP2) and a procyanidin (DP8). The interactions were tested in identical conditions for both methods. The association constants determined by isothermal titration calorimetry (expressed as constitutive unit) varied with the following scale: PLP-DP8 >> BSA-DP8 $\approx$ BSA-DP2 $\approx$ PLP-DP2 > BSA-EPI (no affinity detected for PLP-EPI). However aggregates formed more readily for highly polymerized procyanidins DP8 with BSA than with PLP, and the scale (with $10 \mathrm{mmol} / \mathrm{L}$ of constitutive unit of polyphenol and $0.07 \mathrm{mmol} /$ L of proteins) was: BSA-DP8 > BSA-DP2 >> PLP-DP8 > PLP-DP2 $\approx$ PLP-EPI, with no haze formation for BSA-EPI. However the impact of polyphenol concentration on haze formation and precipitation was different for the two proteins.
\end{abstract}

\section{Introduction}

Interactions between proteins and polyphenols are well known and have been measured by many methods. The aggregates/haze formation was the first method used for interactions amongst tannins and proteins (Hagerman \& Butler, 1981). New, more specific methods are now proposed, such as isothermal titration calorimetry (ITC) measuring changes of energy caused by reversible interactions (Frazier et al., 2010; Frazier, Papadopoulou, \& Green, 2006; Frazier, Papadopoulou, Mueller-Harvey, Kissoon, \& Green, 2003; McRae, Falconer, \& Kennedy, 2010; Pascal et al., 2007; Poncet-Legrand, Gautier, Cheynier, \& Imberty, 2007). ITC allows working in solution with known concentrations of compounds, defining thermodynamic parameters and strengths of interactions. However, it does not distinguish specific from non-specific

* Corresponding author. INRA, UMR408 Sécurité et Qualité des Produits d'Origine Végétale, Domaine St-Paul, Site Agroparc, 84914, Avignon Cedex 9, France. Tel.: +33 (0) 4327225 37; fax: +33 (0) 432722492.

E-mail address: watrelotaude@yahoo.fr (A.A. Watrelot). interactions and is not sensitive to sample turbidity during the titration, or to weak interactions obtained with flavan-3-ols monomers and pectins (Watrelot, Le Bourvellec, Imberty, and Renard (2013)). Moreover, interpretation can be difficult because polyphenol-protein interactions do not follow the classical "lock and key" model, due to stacking and cooperativity (Baxter, Lilley, Haslam, \& Williamson, 1997; Cala et al., 2010). It has been applied mostly for affinity between wine tannin (procyanidins with galloyl groups) and salivary proteins (McRae \& Kennedy, 2011; Pascal et al., 2007; Rinaldi, Jourdes, Teissedre, \& Moio, 2014). One question is therefore how to relate the ITC affinities and energy to the older studies that have used aggregation.

Proline rich-proteins (PRPs) represent $70 \%$ of salivary proteins (Bennick, 1982). Their composition is $40 \%$ proline, $21 \%$ glycine and 17\% glutamine (Mehansho, Butler, \& Carlson, 1987), and are unstructured (Williamson, 1994). Their interactions with tannins, and notably procyanidins (condensed tannins) has been studied in relation to astringency, i.e. in-mouth precipitation of salivary proteins by tannins (Hagerman \& Butler, 1981; Ma et al., 2014). Bovine serum albumin (BSA) is a globular protein frequently used in 
protein-polyphenol interaction studies (Ferrer-Gallego, Gonçalves, Rivas-Gonzalo, Escribano-Bailón, \& de Freitas, 2012; Frazier et al., 2006, 2003; Prigent et al., 2009).

Polyphenols such as flavan-3-ols (monomers and procyanidin oligomers) with various degree of polymerization (DP) strongly influences interactions with proteins (Sun et al., 2013). Proteinpolyphenol associations may be influenced by either protein structure or composition (Bohin, Vincken, van der Hijden, \& Gruppen, 2012) and external conditions such as ionic strength (Rawel, Meidtner, \& Kroll, 2005), pH (Prigent et al., 2003), alcohol (King, Dunn, \& Heymann, 2013), protein to polyphenol ratio (Pascal et al., 2007), or polyphenol structure and composition.

Procyanidins are characterized by their constitutive units, type of linkages and DP (Hemingway \& Karchesy, 1989). Procyanidins of apple parenchyma are archetypes of the procyanidin class, being constituted of (-)-epicatechin ( $90 \%$ of constitutive units) present in extension and terminal units and a few $(+)$-catechin present only as terminal units (Sanoner, Guyot, Marnet, Molle, \& Drilleau, 1999). Those monomers are linked by carbon-carbon inter-flavan bonds (corresponding to B-type procyanidins) mostly between C4 and C8, with variable number of constitutive units (defined as the numberaverage degree of polymerization DPn).

The objective of this study was to connect the formation of aggregates/haze to energy, affinity or stoichiometry obtained by ITC for analysis of polyphenol-protein interaction, using a protein and a polypeptide (BSA and PLP respectively) and procyanidins differing by their DP, and hence their potential of interaction.

\section{Material and methods}

\subsection{Chemicals}

Methanol, acetonitrile, and acetone of chromatographic quality were from Biosolve (Distribio, Evry, France), hexane of analytical quality from Merck (Darmstadt, Germany), ethanol from Fisher Scientific (Strasbourg, France), toluene- $\alpha$-thiol from Sigma-Aldrich (Deisenhofen, Germany).

Chlorogenic acid (purity 95\%), (+)-catechin (purity 98\%), (-)-epicatechin (purity 90\%), bovine serum albumin ( $\mathrm{Mw}=$ $66,430 \mathrm{Da}$, purity $\geq 98 \%$ ) and poly-L-proline (Mw = $6900 \mathrm{Da}$, purity 98\%) were from Sigma-Aldrich, 4-Coumaric acid (purity 90\%) from Extrasynthese (Lyon, France) and phloridzin (purity 99\%) from Fluka (Buchs, Switzerland).

\subsection{Plant material preparation}

Apples (Malus $\times$ domestica Borkh.) cv. "Kermerrien" were harvested at commercial maturity in 2011 in the experimental orchard of the Institut Français des Productions Cidricoles (IFPC, Sées, France). "Golden delicious" apples were collected in July 2010 in the orchard of Mrs H. Girardin (Avignon, France) to have high flavan-3ols contents as described by Renard, Dupont, and Guillermin (2007). Fruits were mechanically peeled and cored as described by Sanoner et al. (1999); cortex tissues were freeze-dried and stored at $-20^{\circ} \mathrm{C}$.

\subsection{Procyanidins extraction and purification}

Hexane, methanol and aqueous acetone extracts of apple polyphenols were obtained by successive solvent extractions of freezedried apple as described (Watrelot et al., 2013).

\subsubsection{Dimer DP2}

Methanolic extracts from "Kermerrien" were centrifuged $\left(16,000 \mathrm{~g}, 15 \mathrm{~min}, 4^{\circ} \mathrm{C}\right)$ and the supernatant was purified by semipreparative HPLC as follows.
First, polyphenols were purified on a reverse phase of silica gel Lichrospher 100 RP $1812 \mu \mathrm{m}$ (Merck, Darmstadt, Germany) with a Hibar $205 \times 25 \mathrm{~mm}$ column. Polyphenols were eluted at $15 \mathrm{~mL} / \mathrm{min}$ at $35{ }^{\circ} \mathrm{C}$, using a gradient of A water/acetic acid $(97.5 / 2.5, \mathrm{~mL} / \mathrm{mL})$ and $\mathrm{B}$ acetonitrile. The gradient was: $0-5 \mathrm{~min}, 0-30 \% \mathrm{~B} ; 5-20 \mathrm{~min}$, $30-30 \%$ B; 20-22 min, 30-90\% B; 22-27 min, $90-90 \%$ B; 27-35 min, 90-0\% B. Polyphenols were collected, concentrated and freeze-dried.

Next, the polyphenols were dissolved at $150 \mathrm{mg} / \mathrm{mL}$ in a $5 / 95$, $\mathrm{mL} / \mathrm{mL}$ mixture of A (methanol/water/acetic acid, $95 / 3 / 2, \mathrm{~mL} / \mathrm{mL}$ / $\mathrm{mL}$ ) and $\mathrm{B}$ (acetonitrile), and eluted on a Luna $5 \mu \mathrm{m}$ HILIC $200 \mathrm{~A}$ AXIA packed, $250 \times 21.2 \mathrm{~mm}$ (Phenomenex, Torrence, CA, USA) with a method adapted from Robbins et al., (2009). Monomers and oligomers were separated using the gradient: $0-3 \mathrm{~min}, 95 \% \mathrm{~B}$; 3-57 min, 32.4\% B; 57-60 min, 0\% B; 60-67 min, 0\% B; 67-70 min, $95 \%$ B. The dimer was collected from 13 to 17 min after the beginning of the gradient. The purified fraction was named DP2.

\subsubsection{Procyanidins DP8}

Freeze-dried aqueous acetone extracts from "Golden delicious" were dissolved in acidified water (water/acetic acid 97.5/2.5, mL/ $\mathrm{mL}$ ) and injected on a C18 SPE column with $20 \mathrm{~mL}$ of solid phase (Bond Elut, Agilent, Les Ulis, France). After washing the column with purified water (Milli-Q, Millipore) to discard non polyphenolic compounds, then ethanol/water $(10 / 90, \mathrm{~mL} / \mathrm{mL})$ to discard monomers, procyanidins were eluted by acetone/water/acetic acid (39/ $60 / 1, \mathrm{~mL} / \mathrm{mL} / \mathrm{mL}$ ). This purified fraction was designated as DP8.

\subsection{Analysis of procyanidins}

Procyanidins were measured by HPLC-DAD after thioacidolysis as described by Le Bourvellec et al., (2011). Analyses were performed using an Ultra Fast Liquid Chromatography Shimadzu Prominence system (Kyoto, Japan) including two pumps LC-20AD Prominence liquid chromatograph UFLC, a DGU-20A5 Prominence degasser, a SIL-20ACHT Prominence autosampler, a CTO-20AC Prominence column oven, a SPD-M20A Prominence diode array detector, a CBM-20A Prominence communication bus module and controlled by LC Solution software (Shimadzu, Kyoto, Japan). The $\overline{D P} \mathrm{n}$ of procyanidins was calculated as the molar ratio of all the flavan-3-ol (thioether adducts plus terminal units) to (-)-epicatechin and $(+)$-catechin terminal units.

\subsection{Determination of thermodynamic parameters of protein- procyanidin associations}

A TAM III microcalorimeter (TA instruments, New Castle, USA) was used. Purified procyanidins $(10 \mathrm{mmol} / \mathrm{L}$ in (-)-epicatechin equivalent), (-)-epicatechin $(10 \mathrm{mmol} / \mathrm{L})$ and proteins $(0.07 \mathrm{mmol} /$ L) were dissolved in the same citrate/phosphate buffer $\mathrm{pH} 3.8$, ionic strength $0.1 \mathrm{~mol} / \mathrm{L}$, filtered on $0.45 \mu \mathrm{m}$ membrane. Physicochemical conditions $\left(25^{\circ} \mathrm{C}, \mathrm{pH} 3.8\right.$ corresponding to the apple $\mathrm{pH}$ and ionic strength $0.1 \mathrm{~mol} / \mathrm{L}$ ) were chosen from previous experiments (Watrelot et al., 2013). All solutions were degassed prior to measurements. The reference cell was filled by water. To obtain a hyperbole curve, as recommended for low affinity systems, different concentrations were tested $(0.05 \mathrm{mmol} / \mathrm{L}$ protein with $10 \mathrm{mmol} / \mathrm{L}$ polyphenol and $0.07 \mathrm{mmol} / \mathrm{L}$ protein with $5 \mathrm{mmol} / \mathrm{L}$ polyphenol). The protein solution was placed in the $850 \mu \mathrm{L}$ sample cell of the calorimeter and the procyanidin solution was loaded into the injection syringe and titrated into the sample cell by 25 injections of $10 \mu \mathrm{L}$ aliquots. The duration of each injection was $20 \mathrm{~s}$, the separating delay $5 \mathrm{~min}$. The contents of the sample cell were stirred throughout the experiment at $90 \mathrm{rev} / \mathrm{min}$. Experiments were done in duplicates. 
Raw data obtained as a plot of heat flow $(\mu \mathrm{J} / \mathrm{s})$ against time (min) was integrated peak-by-peak and normalized using Nanoanalyze software v2.4.1 (TA instruments software) to obtain a plot of observed enthalpy change per mole of injectant $(\Delta \mathrm{H}, \mathrm{kJ} / \mathrm{mol})$ against the molar ratio (epicatechin/protein). Titration of procyanidin fractions into buffer (controls) were subtracted from titration experiments. The experimental data were fitted to a theoretical titration curve using Nanoanalyze, with $\Delta H$ (enthalpy change), $K_{a}$ (association constant), and $n$ (number of binding sites per molecule) as adjustable parameters, from the relationship

$$
\begin{aligned}
Q_{i}= & \frac{n P_{t} \Delta H V_{0}}{2}\left[1+\frac{A_{t}}{n P_{t}}+\frac{1}{n K_{a} P_{t}}\right. \\
& \left.-\sqrt{\left(1+\frac{A_{t}}{n P_{t}}+\frac{1}{n K_{a} P_{t}}\right)^{2}-4 \frac{A_{t}}{n P_{t}}}\right]
\end{aligned}
$$

where $P_{\mathrm{t}}$ was the protein concentration in mol/L, $A_{\mathrm{t}}$ was the total (-)-epicatechin concentration in $\mathrm{mol} / \mathrm{L}, V_{0}$ was the volume of the cell, and $Q_{i}$ was the total heat released for injection $i$. The one set of independent binding sites was chosen because analyses were expressed in constitutive unit equivalent and results were correctly fitted using that model.

The thermodynamic parameters were calculated from the van't Hoff equation:

$\Delta G=-R T \ln K_{a}=\Delta H-T \Delta S$

where $\Delta G$ was free enthalpy, $K_{a}$ was the association constant, $\Delta H$ was the enthalpy and $\Delta S$ was the entropy of reaction.

The goodness-of-fit and confidence intervals were measured by the statistic system of the Nanoanalyze software. For a confidence level of $95 \%, 100$ trials were carried out with a standard deviation of 2 on the independent model (Eq. (1)).

\subsection{Haze/aggregate formation by protein-procyanidin interactions}

Formation of aggregates during protein-tannin interactions was identified by spectrophotometry. This experiment was done in triplicates. Systematic variation of ratios was carried out on a 96well microplate at $25^{\circ} \mathrm{C}$, by a serial dilution of procyanidins $(0$, $0.5,1,2,4,6,8$ and $10 \mathrm{mmol} / \mathrm{L}$ (-)-epicatechin equivalent) along the lines and a serial dilution of proteins $(0,0.01,0.02,0.03,0.04,0.05$, 0.06 and $0.07 \mathrm{mmol} / \mathrm{L}$ ) along the columns. Solutions were prepared in citrate/phosphate buffer at $\mathrm{pH} 3.8$ and ionic strength $0.1 \mathrm{~mol} / \mathrm{L}$. Equal amounts $(50 \mu \mathrm{L})$ of procyanidins and proteins solutions were stirred for $20 \mathrm{~s}$ by the microplate reader before each measurement. Absorbances at $650 \mathrm{~nm}$ were recorded for each well using a SAFAS flx-Xenius XM spectrofluorimeter (SAFAS, Monaco). Control wells contained only proteins or procyanidins in buffer. After recording, microplates were centrifuged $10 \mathrm{~min}$ at $2100 \mathrm{~g}\left(20^{\circ} \mathrm{C}\right)$ and supernatants of control well (procyanidins at $10 \mathrm{mmol} / \mathrm{L}$ in buffer (named S1)) and of wells containing procyanidins at a concentration of $10 \mathrm{mmol} / \mathrm{L}$ with proteins at a concentration of $0.07 \mathrm{mmol} / \mathrm{L}$ (named S2) were analyzed as described in $\S 2.4$. to identify changes in number-average degree of polymerization $(\Delta \overline{\mathrm{DP}} \mathrm{n}=\mathrm{S} 2-\mathrm{S} 1)$.

\section{Results}

\subsection{Procyanidins characterization}

The methanolic extract of "Kermerrien" yielded dimers with a purity of almost $90 \%$ after two purification steps (Table 1). The dimer preparation included procyanidins B2 ((-)-epicatechin- (-)-epicatechin) and B1 ((-)-epicatechin-(+)-catechin), the latter representing $15 \%$ of total procyanidins. After thioacidolysis, (-)-epicatechin represented $91 \%$ of total flavanol unit and (+)-catechin only $9 \%$, in good agreement with quantification of B2 and B1 dimers. Less than 1\% polyphenolic contaminant (caffeoylquinic acid) was detected.

The purified extract from "Golden delicious" contained more than $670 \mathrm{mg} / \mathrm{g}$ polyphenols, mainly procyanidins $(83 \%$ of total polyphenols), plus traces of hydroxycinnamic acids, mainly caffeoylquinic acid. The rest (33\%) of the extract might be organic acids or sugars, or structural water (Table 1). The major constitutive unit was (-)-epicatechin both in extension and terminal units (97\%); (+)-catechin (3\% of units) was present exclusively in terminal units (Watrelot et al., 2013). The average degree of polymerization was 8 , hence the purified fraction was designated DP8.

\subsection{Interactions using ITC}

Titration of BSA by flavan-3-ol monomer ((-)-epicatechin) and procyanidins DP2 and DP8 showed strong exothermic peaks (Fig. 1 A). After subtraction of respective controls, the peak areas were plotted against the polyphenol-to-protein molar ratio and the resulting curve was fitted with the independent model (Eq. (1)) and confidence intervals of thermodynamic parameters were calculated by the software (Table 2). Energy generated at the beginning of titration by (-)-epicatechin was about $-4 \mathrm{~kJ} / \mathrm{mol}$, strangely lower at $-1 \mathrm{~kJ} / \mathrm{mol}$ by DP2 and higher at $-7 \mathrm{~kJ} / \mathrm{mol}$ by DP8 (Fig. $1 \mathrm{~A}$ ). Stoichiometry values of 5, 13 and 61 expressed as (-)-epicatechin unit were obtained for (-)-epicatechin, dimer and procyanidins DP8, respectively (Table 2). However, the confidence interval of the stoichiometry for (-)-epicatechin and BSA was high (2.4) because of the non-sigmoidal curve, which means that result must be taken with caution. Molar ratio ((-)-epicatechin/BSA) showed that 5 moles of (-)-epicatechin were able to bind to 1 mole of BSA. The stoichiometry value of 13 when expressed in (-)-epicatechin equivalent indicated that approximately 6 moles of dimer bind to 1 mole of BSA. For procyanidins DP8, again expressed as (-)-epicatechin units, the stoichiometry was higher than 60 (-)-epicatechin units per mole of BSA, which might be due to the fact that binding sites were not yet saturated at the end of the titration. However it is not possible to directly translate this in moles of procyanidin molecules as DP8 contained individual molecules of different DPs. With the approximation using DPn, the stoichiometry value was ca. 9 .

The affinity for (-)-epicatechin $(\mathrm{Ka}=459 \mathrm{~L} / \mathrm{mol})$ was similar to that observed by Frazier et al. (2006). Affinity constants between 2200 and $2300 \mathrm{~L} / \mathrm{mol}$ of monomer unit were similar for DP2 and DP8. However, conclusions differed if affinity constants were expressed per procyanidin molecule. Though these results must be interpreted with care due to polydispersity, affinity increased with

\section{Table 1}

Characterization of procyanidins DP2 and DP8 from Kermerrien and Golden deli-

\begin{tabular}{|c|c|c|c|c|c|c|c|c|}
\hline & \multirow[t]{3}{*}{ DPn } & \multicolumn{3}{|c|}{ Procyanidins } & \multicolumn{2}{|c|}{ Dihydrochalcones } & \multicolumn{2}{|c|}{ Hydroxycinnamic acids } \\
\hline & & \multirow{2}{*}{$\frac{\text { Extension }}{\text { EPI }}$} & \multicolumn{2}{|c|}{ Terminal } & \multirow[t]{2}{*}{ PLZ } & \multirow[t]{2}{*}{ XPL } & \multirow[t]{2}{*}{ CQA } & \multirow[t]{2}{*}{ PCQ } \\
\hline & & & EPI & CAT & & & & \\
\hline DP2 & 2 & 464 & 333 & 79 & 0 & 0 & 8 & 0 \\
\hline DP8 & 8 & 562 & 64 & 21 & 1 & 0 & 25 & 1 \\
\hline$S D$ & 0.5 & 43.4 & 1.1 & 0.4 & 0.1 & nd & 7.1 & nd \\
\hline
\end{tabular}
cious respectively $(\mathrm{mg} / \mathrm{g}$ of dry matter).

DPn: average degree of polymerization of procyanidins; CAT: $(+)$-catechin; EPI (-)-epicatechin; PLZ: phloridzin; XPL: phloretin xyloglucoside; CQA: caffeoylquinic acid; PCQ: para-coumaroylquinic acid; SD: pooled standard deviation; nd: not defined. 
Version définitive du manuscrit publiée dans / Final version of the manuscript published in :

LWT - Food Science and Technology (2015), Vol. 63, p. 376-382, DOI: 10.1016/j.Iwt.2015.03.064

Journal homepage : http://www.elsevier.com/loc,ate/lwt

A
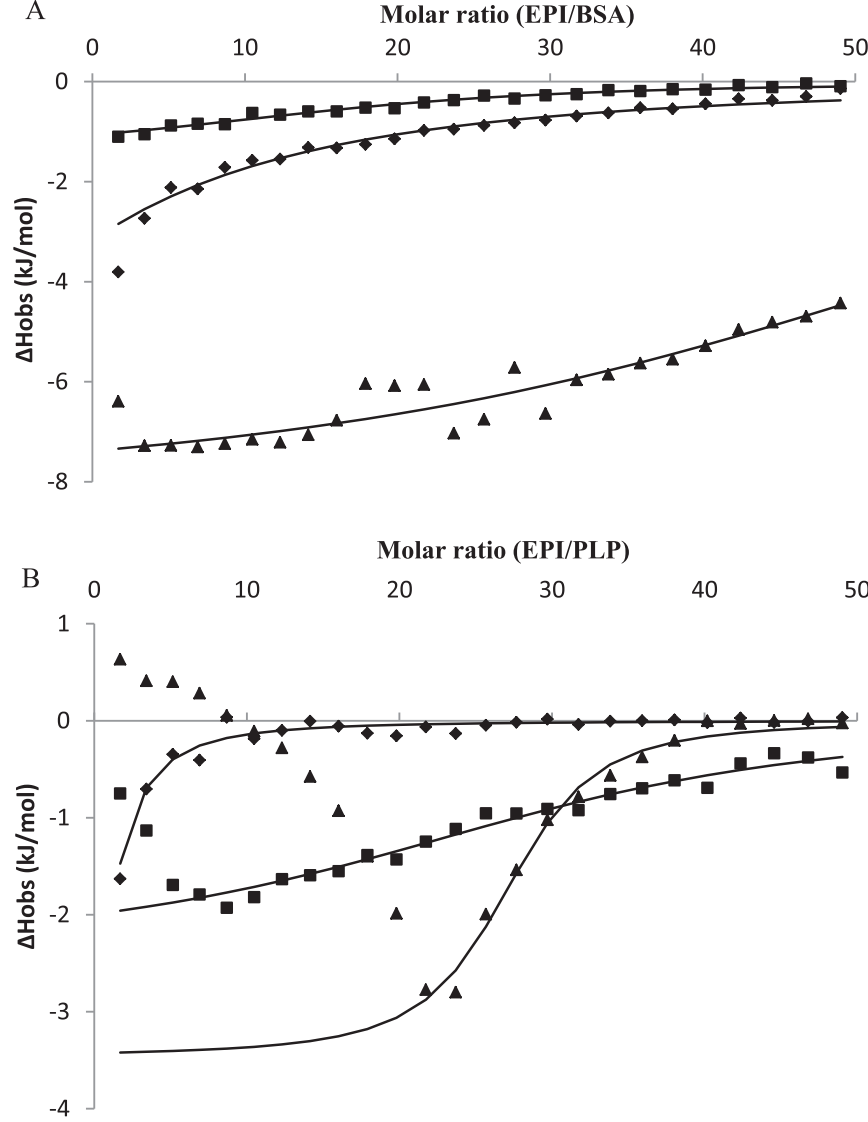

Fig. 1. Isothermal titration calorimetry $\left(25^{\circ} \mathrm{C}, \mathrm{pH} 3.8\right.$ and ionic strength $\left.0.1 \mathrm{~mol} / \mathrm{L}\right)$ of bovine serum albumin (BSA) (A) and poly-L-proline (PLP) (B) titrated by flavan-3-ols of various average degree of polymerization (in duplicates): $\bullet$ (-)-epicatechin (EPI); procyanidin DP2 and $\boldsymbol{\Delta}$ procyanidins DP8. — Fitted data.

DP and Ka value between BSA and DP8 was similar to that obtained between BSA and sorghum procyanidins (Frazier et al. (2010)). Negative enthalpy from $-24 \mathrm{~kJ} / \mathrm{mol}$ to $-2 \mathrm{~kJ} / \mathrm{mol}$ for (-)-epicatechin and dimer respectively showed exothermic interaction (Table 2). However, the confidence interval of enthalpy for (-)-epicatechin BSA interaction was very similar to the enthalpy value $(-24 \pm 18 \mathrm{~kJ} /$ mol). Free enthalpy $(\Delta G)$ was negative which indicated a spontaneous interaction, and similar with all procyanidins. The entropy $\operatorname{term}(\Delta \mathrm{S})$ was negative in the case of $(-)$-epicatechin $(-29 \mathrm{~J} / \mathrm{mol} / \mathrm{K})$. Conversely, the entropy term was positive for the dimer and DP8 (58 and $38 \mathrm{~J} / \mathrm{mol} / \mathrm{K}$ respectively) (Table 2 ).

The titration of poly-L-proline (PLP) by (-)-epicatechin led to endothermic peaks. After subtraction of control ((-)-epicatechin in buffer) no curve was obtained and no titration could be observed (Fig. 1 B). Though Baxter et al., (1997) could measure a low dissociation constant for PLP and (-)-epicatechin complexes, here no thermodynamic parameters were obtained (Table 2). However, titration of PLP by the DP2 showed strong exothermic peaks with energy generated of $-2 \mathrm{~kJ} / \mathrm{mol}$. Titration of PLP by procyanidin DP8 showed two phases (Fig. 1 B). During the first six injections endothermic peaks were obtained. From the seventh injection, exothermic peaks appeared and energy generated increased up to $-3 \mathrm{~kJ} / \mathrm{mol}$. Then, from the thirteenth injection, energy generated decreased, corresponding to saturation of binding sites. Due to signal complexity, the last part of data were fitted by an independent model to obtain thermodynamic parameters presented in Table 2. Using the independent model, stoichiometry expressed as (-)-epicatechin unit for DP2 was higher than for DP8, with 1 mole of PLP able to bind with 26 moles of constitutive unit of the dimer (13 moles of dimer DP2) but only with 22 moles of constitutive units of DP8. Again with the approximation of monodispersity, 3 moles of DP8 would bind with 1 mole of PLP. The low stoichiometry for association between PLP and procyanidin DP8 could be due to the polyphenol conformation and would explain the complexity of the microcalorimetry signal. Affinity constants for DP8 was more than 25 times that of DP2, whether when expressed as constitutive unit or procyanidin unit, but could be influenced by a cooperative effect such as stacking of procyanidins DP8 on PLP and pre-existing PLP-DP8 complexes. Association constant of DP8 PLP was in agreement with Poncet-Legrand et al. (2007) between DP4 and PLP, probably because in our study the procyanidin concentration was expressed in monomer equivalent and higher $(10 \mathrm{mmol} / \mathrm{L})$ than DP4 used by Poncet-Legrand et al. ( $4 \mathrm{mmol} / \mathrm{L})$ expressed in molecule. Enthalpy was similar whatever the degree of polymerization of procyanidins $(-3 \mathrm{~kJ} / \mathrm{mol})$ and the free enthalpy was negative corresponding to a spontaneous reaction. In both cases, the entropy term $(\Delta \mathrm{S})$ was positive $(53$ and $78 \mathrm{~J} / \mathrm{mol} / \mathrm{K}$ for DP2 and DP8 respectively), suggesting hydrophobic interactions (Table 2). A two-sets of independent binding sites model was also tested: the enthalpy for the first part of the signal was negative $(-32 \mathrm{~kJ} / \mathrm{mol})$ with a positive entropy while the second part of the signal had a positive enthalpy ( $8 \mathrm{~kJ} / \mathrm{mol}$ ) and positive entropy (not shown).

\subsection{Haze/aggregates formation}

Absorbance at $650 \mathrm{~nm}$ was used as a marker of haze formation, because neither proteins nor procyanidins absorb at this wavelength. Absorbance at $650 \mathrm{~nm}$ in wells with (-)-epicatechin or DP2 was null whatever their concentration (Figs. 2A, C, 3A, C). Absorbance at $650 \mathrm{~nm}$ for DP8 alone was 0.1 whatever the concentration (Figs. 2E and 3E): DP8 alone formed a slight haze, as observed by Watrelot et al. (2013) for procyanidins DP9. This confirmed that procyanidins of low degree of polymerization (in DP8) selfassociate in colloidal aggregates (Poncet-Legrand et al., 2006).

Whatever the concentrations of (-)-epicatechin and BSA, absorbance at $650 \mathrm{~nm}$ stayed null (Fig. $2 \mathrm{~A}$ and B). Interaction

Table 2

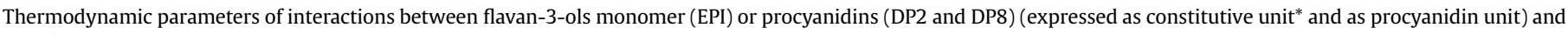
proteins.

\begin{tabular}{|c|c|c|c|c|c|c|c|c|c|c|}
\hline & \multicolumn{5}{|l|}{ BSA } & \multicolumn{5}{|l|}{ PLP } \\
\hline & EPI & $\mathrm{DP} 2 *$ & DP8* & DP2 & DP8 & EPI & DP2* & DP8* & DP2 & DP8 \\
\hline $\mathrm{n}$ & $5 \pm 2.4$ & $13 \pm 1.3$ & $61 \pm 0.7$ & $6 \pm 0.8$ & $9 \pm 0.1$ & - & $26 \pm 1.0$ & $22 \pm 0.2$ & $13 \pm 0.4$ & $3 \pm 0.02$ \\
\hline $\mathrm{Ka}(\mathrm{L} / \mathrm{mol})$ & $459 \pm 54$ & $2,248 \pm 457$ & $2,379 \pm 126$ & $3,865 \pm 1,008$ & $16,964 \pm 1,140$ & - & $1,971 \pm 212$ & $51,180 \pm 4,067$ & $3,930 \pm 326$ & $362,500 \pm 26,350$ \\
\hline$\Delta \mathrm{H}(\mathrm{kJ} / \mathrm{mol})$ & $-24 \pm 18.0$ & $-2 \pm 0.6$ & $-8 \pm 0.1$ & $-4 \pm 1.3$ & $-57 \pm 0.4$ & - & $-3 \pm 0.2$ & $-3 \pm 0.1$ & $-5 \pm 0.3$ & $-25 \pm 0.8$ \\
\hline$\Delta \mathrm{G}(\mathrm{kJ} / \mathrm{mol})$ & -15 & -19 & -19 & -25 & -24 & - & -19 & -27 & -20 & -32 \\
\hline$\Delta \mathrm{S}(\mathrm{J} / \mathrm{mol} / \mathrm{K})$ & -29 & 58 & 38 & 55 & -112 & - & 53 & 78 & 50 & 21 \\
\hline
\end{tabular}

BSA: bovine serum albumin; PLP: poly-L-proline; EPI: (-)-epicatechin; n: stoichiometry; Ka: affinity constant; $\Delta \mathrm{H}$ : enthalpy; $\Delta \mathrm{G}$ : free enthalpy; $\Delta \mathrm{S}$ : entropy. 
Version définitive du manuscrit publiée dans / Final version of the manuscript published in :

LWT - Food Science and Technology (2015), Vol. 63, p. 376-382, DOI: 10.1016/j.Iwt.2015.03.064

Journal homepage : http://www.elsevier.com/locate/lwt

between (-)-epicatechin and BSA did not cause haze formation. An increase of absorbance at $650 \mathrm{~nm}$ was obtained with BSA at $0.07 \mathrm{mmol} / \mathrm{L}$ and the dimer DP2 from $4 \mathrm{mmol} / \mathrm{L}$ of the dimer. Absorbance increased until 0.7 at $10 \mathrm{mmol} / \mathrm{L}$ of DP2 (Fig. 2C), and increased from $0.01 \mathrm{mmol} / \mathrm{L}$ of BSA when concentration of dimer DP2 was fixed at $10 \mathrm{mmol} / \mathrm{L}$ in (-)-epicatechin equivalent (Fig. $2 \mathrm{D}$ ). With low concentrations of dimer $(\leq 4 \mathrm{mmol} / \mathrm{L})$, association with the globular protein caused neither haze nor aggregates formation. However, with BSA and dimer $\geq 4 \mathrm{mmol} / \mathrm{L}$, haze was formed, probably due to cross-linking of proteins by dimers. Absorbance at $650 \mathrm{~nm}$ in wells containing DP8 and BSA at $0.07 \mathrm{mmol} / \mathrm{L}$ increased sharply from $0.5 \mathrm{mmol} / \mathrm{L}$ up to $4 \mathrm{mmol} / \mathrm{L}$ of DP8 in (-)-epicatechin equivalent from 0 until 0.9 , then stabilized until $10 \mathrm{mmol} / \mathrm{L}$ of DP8 (Fig. 2 E), maybe due to sedimentation of DP8-BSA complexes. Moreover, absorbance at $650 \mathrm{~nm}$ at $10 \mathrm{mmol} / \mathrm{L}$ of DP8 increased steadily from 0.1 until 0.9 with the increase of BSA concentrations (Fig. 2 F).

The DPn of the non-coprecipitated procyanidins (present in supernatants after interaction with BSA) decreased by 2.5 (Table 3). This lower DPn indicated preferential association of BSA with highly polymerized procyanidins, as observed by Watrelot et al. (2013) between commercial pectins and procyanidins DP9 or DP30.

Association between PLP and (-)-epicatechin led to a very slight increase of absorbance at $650 \mathrm{~nm}$ (Fig. $3 \mathrm{~A}$ and B) up to 0.1 from $8 \mathrm{mmol} / \mathrm{L}$ of (-)-epicatechin with $0.07 \mathrm{mmol} / \mathrm{L}$ of PLP. It was too small to be a haze. Moreover, association of PLP with the dimer DP2 showed a very slight increase of absorbance at $650 \mathrm{~nm}$ starting from $0.5 \mathrm{mmol} / \mathrm{L}$ in (-)-epicatechin equivalent (Fig. 3C). Then absorbance at $650 \mathrm{~nm}$ stabilized at 0.09 , whatever the concentrations of protein and polyphenol (Fig. $3 \mathrm{C}$ and D). Absorbance at $650 \mathrm{~nm}$ with procyanidins DP8 and PLP increased more than procyanidins DP8 alone, up to 0.2 (Fig. $3 \mathrm{E}$ and F). Haze formation was more marked in the presence of both compounds. In the case of DP2 and DP8, standard deviation was greater because haze formed was non-homogenous and the result of soluble aggregates.

After association between PLP and DP8, the degree of polymerization of procyanidins not coprecipitated with proteins, was decreased (7.8 against 8.9 initially). This decrease, though less marked than with BSA, notified that the more polymerized procyanidins bind preferentially with PLP.

\section{Discussion}

Individual interaction experiments were consistent with the preexisting literature. Energy generated by the titration of BSA by (-)-epicatechin was similar to that shown by Frazier et al., (2006) at pH 7.4. Frazier et al. (2010) observed that the higher the DP, the higher the energy generated during interactions with BSA. They also reported that the n-value is limited by the tannins size and not directly related to the number of constitutive units. A higher nvalue with larger molecules, i.e. an increase in apparent number of binding sites on the protein when molecular size of tannins increases might be due to an overlay of procyanidins on the BSA surface (Poncet-Legrand et al., 2006). The affinity "stabilization"
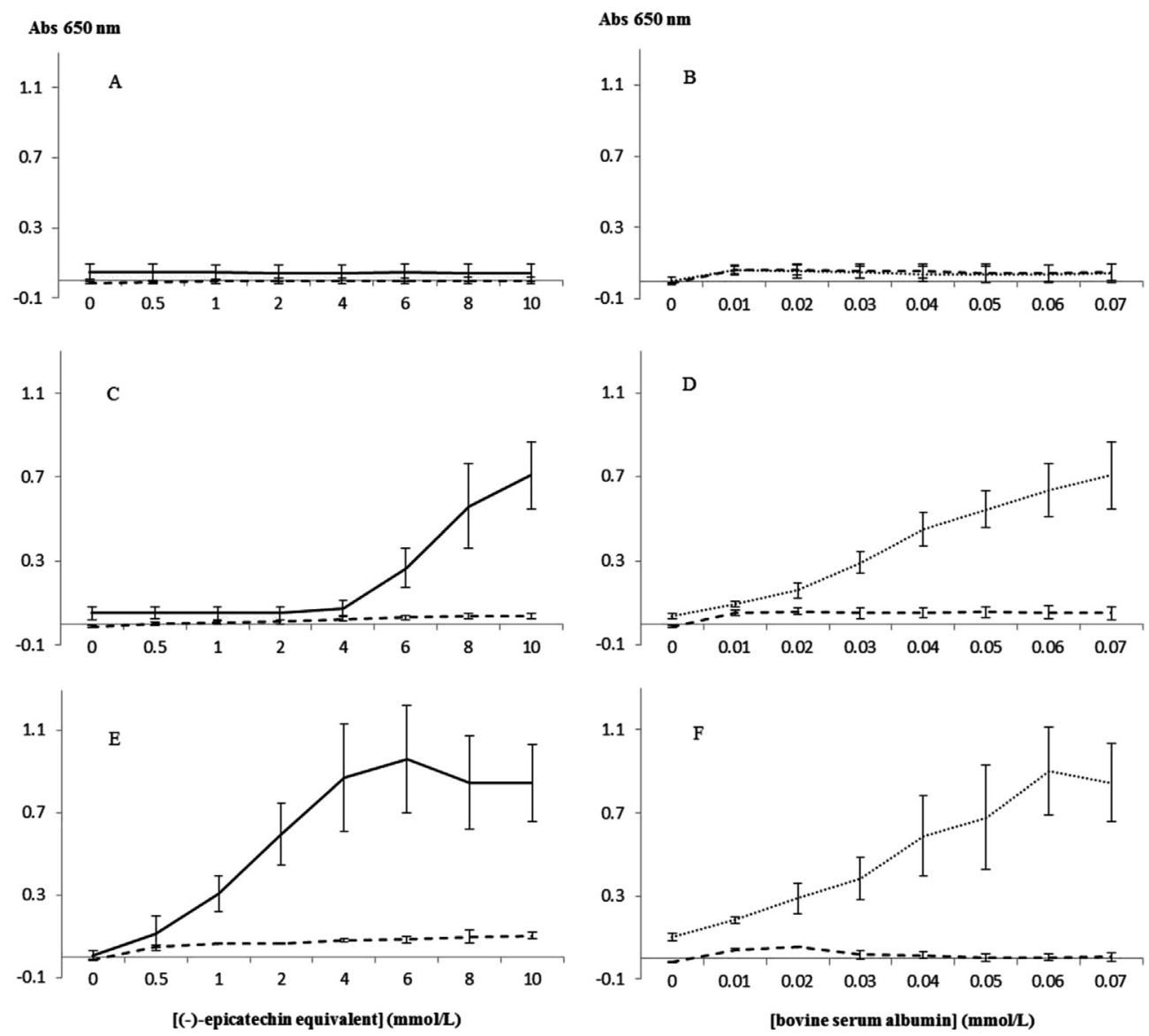

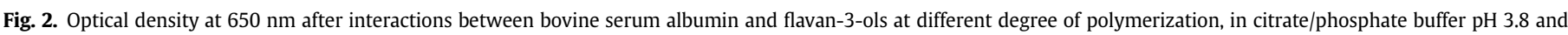

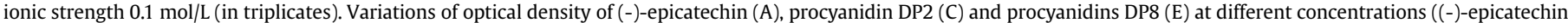

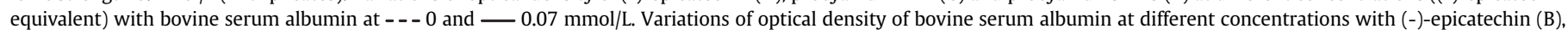
procyanidin DP2 (D) and procyanidins DP8 (F) at - - - 0 and ........ $10 \mathrm{mmol} / \mathrm{L}$ (in (-)-epicatechin equivalent). 

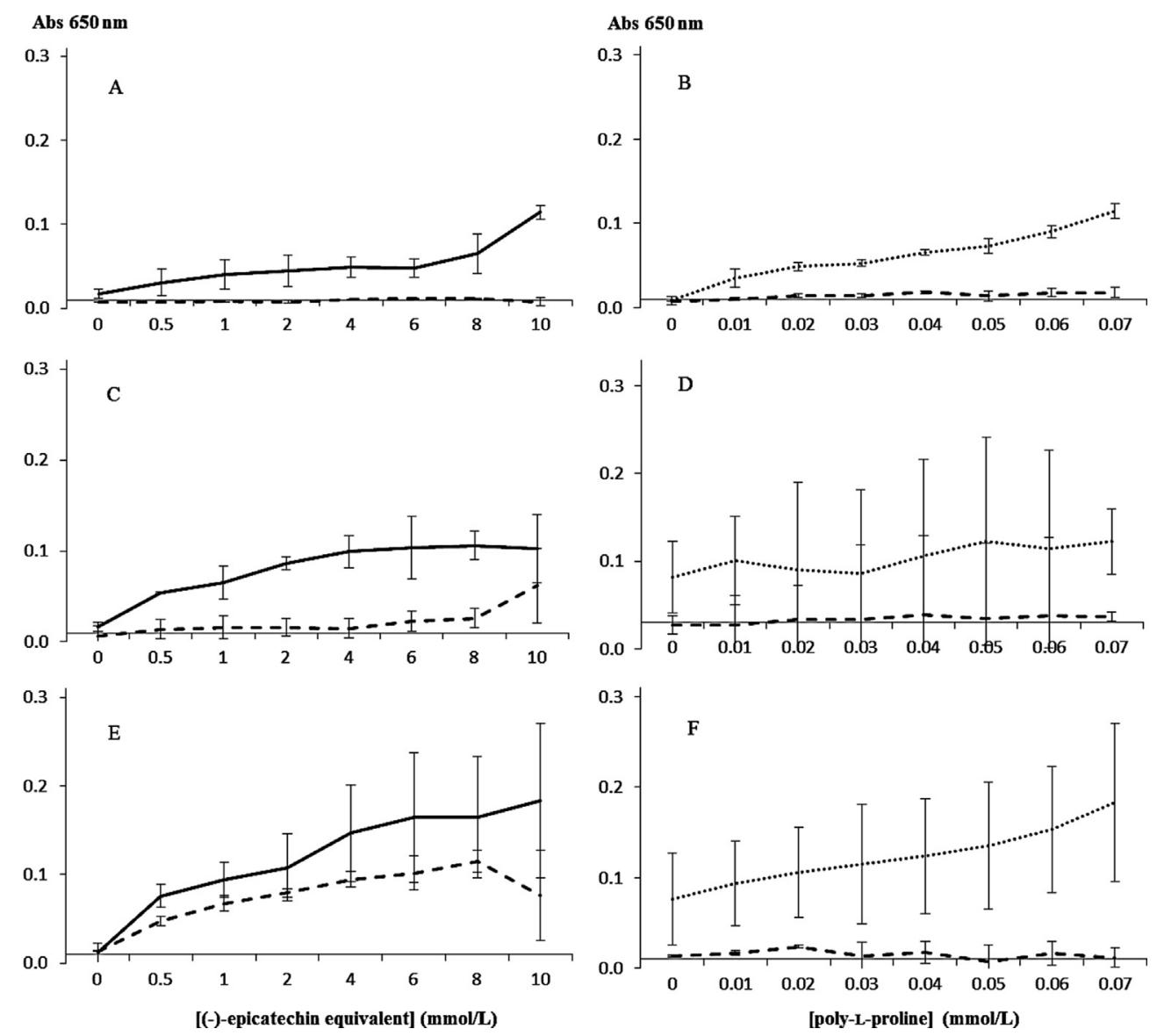

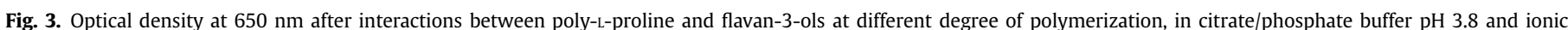

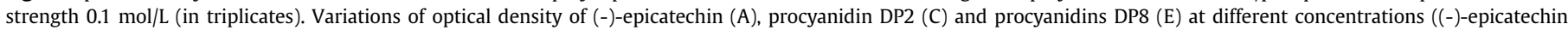

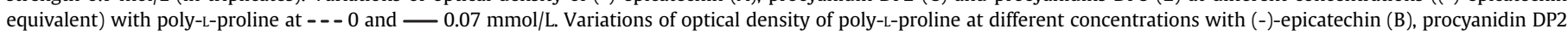
(D) and procyanidins DP8 (F) at --- 0 and ......... $10 \mathrm{mmol} / \mathrm{L}$ (in (-)-epicatechin equivalent).

observed between BSA and DP2 and DP8 may be due to saturation of binding sites by procyanidins. The predominance of a favorable enthalpy term for (-)-epicatechin - BSA association confirmed implication of hydrogen bonds (Frazier et al., 2006; Kríž, Koča, Imberty, Charlot, \& Auzély-Velty, 2003). The positive entropy term for BSA-DP2, BSA-DP8 and PLP-DP8 meant that hydrophobic interactions were favored as main binding mechanism (McRae et al., 2010; Poncet-Legrand et al., 2007). This could be explained as a solvating effect, where (-)-epicatechin was completely dissolved in solvent which allowed interactions through hydrogen bonds, whereas the dimer was less able to link with water which led to hydrophobic interactions, while DP8 could be folded on itself via hydrophobic interactions (Pianet et al., 2008). In the case of PLP, the signal complexity obtained with DP8 was similar to the titration of PRP IB5 by epigallocatechin gallate (Pascal et al., 2007), with interaction followed by individual conformation rearrangements of

Table 3

Degree of polymerization of procyanidins and degree of polymerization of residual procyanidins in supernatant after protein precipitation.

\begin{tabular}{lrr}
\hline DP8 & BSA & PLP \\
\hline DPn before association & 8.2 & 8.9 \\
DPn after association & 5.7 & 7.8 \\
$\Delta$ DPn & -2.5 & -1.1
\end{tabular}

BSA: bovine serum albumin; PLP: poly-L-proline; EPI: (-)-epicatechin; DPn: average of degree of polymerization. polyphenol and stacking leading to protein aggregation and haze formation. Contrary to ITC results, no haze formation was observed between (-)-epicatechin and BSA: the small size of (-)-epicatechin might preclude cross-linking, a prerequisite for aggregation of the globular protein (Hagerman \& Butler, 1981), or pH (charges) might prevent precipitation (Charlton et al., 2002). Interaction with BSA led to haze formation with the dimer and to haze and sedimentation with DP8, which might be due to a cross-linking of proteins by procyanidin oligomers (He et al., 2011).

ITC is based on heat released or absorbed measurements. It is used to determine thermodynamic parameters such as stoichiometry, association constant, enthalpy, free enthalpy and entropy, in order to define the type of bonds implicated in interactions. With this method, concentrations of ligand and proteins are well known and the titration consists in a slow addition of a ligand to a protein always under stirring. It allows detection of any rearrangements due to interactions but has a limit of detection for little heat changes. Moreover, entropy can be related to protein-procyanidin interactions themselves but also to the solubilization of compounds in solvent or to the desolvation phenomenon or to the conformational changes as expressed by Whitesides and Krishnamurthy (2005). Haze formation takes into account the solubility and the desolvation phenomenon. Haze formation is a complex phenomenon, that entails molecules-molecules and molecules-solvent linkages which modify solubility. The turbidity measurement involved a quick agitation at the beginning of the experiment. The lack of stirring during the complete measurement 
might induce a non-homogenous haze/aggregates formation. Moreover, this method was dependent on matrix, such as $\mathrm{pH}$, which is known to impact on precipitation but not on interactions' affinity (Charlton et al., 2002). Those are reasons to use both methods together to extend the understanding on macromolecules interactions.

\section{Conclusions}

Our understanding of structure - affinity relationships for polyphenol-protein interactions was biased by the methodology applied, even with all other conditions being identical. Microcalorimetry allows defining interactions parameters and haze formation shows consequences of interactions. Using microcalorimetry, macromolecules concentrations are known and the experiment consists in a slow addition of polyphenol to a protein, while the turbidity measurement is a macroscopic observation involving the mixing of various concentrations of polyphenol to protein. Neither method is appropriate to distinguish specific from non-specific interactions. Therefore the structure-reactivity relationships established by aggregate/haze formation for protein - tannins interactions will need to be reexamined completely in the new light shed by ITC on this phenomenon. An integrated approach involving multiple different techniques, allowing to observe these interactions from different angles, should be used. A study using a surface plasmon resonance will be realized to further study the mechanisms of interactions between B-type procyanidins and bovine serum albumin or poly-L-proline, since this method implicates the immobilization of one compound on a solid support, requires known concentrations and analyses interactions in real time.

\section{Acknowledgments}

The authors thank Dr. K. Kurtural for careful rereading of English expression. The research leading to these results has received funding from the European Community's Seventh Framework Programme (FP7/2007-2013) under the grant agreement $n^{\circ}$ FP7222 654-DREAM.

\section{References}

Baxter, N. J., Lilley, T. H., Haslam, E., \& Williamson, M. P. (1997). Multiple interactions between polyphenols and a salivary proline-rich protein repeat result in complexation and precipitation $\dagger$. Biochemistry, 36(18), 5566-5577.

Bennick, A. (1982). Salivary proline-rich proteins. Molecular and Cellular Biochemistry, 45(2), 83-99.

Bohin, M. C., Vincken, J.-P., van der Hijden, H. T. W. M., \& Gruppen, H. (2012). Efficacy of food proteins as carriers for flavonoids. Journal of Agricultural and Food Chemistry, 60(16), 4136-4143.

Cala, O., Pinaud, N., Simon, C., Fouquet, E., Laguerre, M., Dufourc, E. J., et al. (2010), NMR and molecular modeling of wine tannins binding to saliva proteins: revisiting astringency from molecular and colloidal prospects. The FASEB Journal, 24(11), 4281-4290.

Charlton, A. J., Baxter, N. J., Khan, M. L., Moir, A. J. G., Haslam, E., Davies, A. P., et al. (2002). Polyphenol/Peptide binding and precipitation. Journal of Agricultural and Food Chemistry, 50(6), 1593-1601.

Ferrer-Gallego, R., Gonçalves, R., Rivas-Gonzalo, J. C., Escribano-Bailón, M. T., \& de Freitas, V. (2012). Interaction of phenolic compounds with bovine serum albumin (BSA) and $\alpha$-amylase and their relationship to astringency perception. Food Chemistry, 135(2), 651-658.

Frazier, R. A., Deaville, E. R., Green, R. J., Stringano, E., Willoughby, I., Plant, J., et al. (2010). Interactions of tea tannins and condensed tannins with proteins. Journal of Pharmaceutical and Biomedical Analysis, 51(2), 490-495.

Frazier, R. A., Papadopoulou, A., \& Green, R. J. (2006). Isothermal titration calorimetry study of epicatechin binding to serum albumin. Journal of Pharmaceutical and Biomedical Analysis, 41(5), 1602-1605.

Frazier, R. A., Papadopoulou, A., Mueller-Harvey, I., Kissoon, D., \& Green, R. J. (2003). Probing protein-tannin interactions by isothermal titration microcalorimetry. Journal of Agricultural and Food Chemistry, 51(18), 5189-5195.
Hagerman, A. E., \& Butler, L. G. (1981). The specificity of proanthocyanidin-protein interactions. Journal of Biological Chemistry, 256(9), 4494-4497.

He, L., Mu, C., Shi, J., Zhang, Q., Shi, B., \& Lin, W. (2011). Modification of collagen with a natural cross-linker, procyanidin. International Journal of Biological Macromolecules, 48(2), 354-359.

Hemingway, R. W., \& Karchesy, J. J. (1989). Chemistry and significance of condensed tannins (p. 553). New York: Plenum Press.

King, E. S., Dunn, R. L., \& Heymann, H. (2013). The influence of alcohol on the sensory perception of red wines. Food Quality and Preference, 28(1), 235-243.

Kríž, Z., Koča, J., Imberty, A., Charlot, A., \& Auzély-Velty, R. (2003). Investigation of the complexation of $(+)$-catechin by $\beta$-cyclodextrin by a combination of NMR, microcalorimetry and molecular modeling techniques. Organic \& Biomolecular Chemistry, 1(14), 2590-2595.

Le Bourvellec, C., Bouzerzour, K., Ginies, C., Regis, S., Plé, Y., \& Renard, C. M. G. C. (2011). Phenolic and polysaccharidic composition of applesauce is close to that of apple flesh. Journal of Food Composition and Analysis, 24(4-5), 537-547.

Ma, W., Guo, A., Zhang, Y., Wang, H., Liu, Y., \& Li, H. (2014). A review on astringency and bitterness perception of tannins in wine. Trends in Food Science \& Technology, 40(1), 6-19.

McRae, J. M., Falconer, R. J., \& Kennedy, J. A. (2010). Thermodynamics of grape and wine tannin interaction with polyproline: implications for red wine astringency. Journal of Agricultural and Food Chemistry, 58(23), 12510-12518.

McRae, J. M., \& Kennedy, J. A. (2011). Wine and grape tannin interactions with salivary proteins and their impact on astringency: a review of current research. Molecules, 16(3), 2348-2364.

Mehansho, H., Butler, L. G., \& Carlson, D. M. (1987). Dietary tannins and salivary proline-rich proteins: interactions, induction, and defense mechanisms. Annual Review of Nutrition, 7(1), 423-440.

Pascal, C., Poncet-Legrand, C., Imberty, A., Gautier, C., Sarni-Manchado, P., Cheynier, V., et al. (2007). Interactions between a non glycosylated human proline-rich protein and flavan-3-ols are affected by protein concentration and Polyphenol/Protein ratio. Journal of Agricultural and Food Chemistry, 55(12), 4895-4901.

Pianet, I., André, Y., Ducasse, M.-A., Tarascou, I., Lartigue, J.-C., Pinaud, N., et al (2008). Modeling procyanidin self-association processes and understanding their micellar organization: a study by diffusion NMR and molecular mechanics. Langmuir, 24(19), 11027-11035.

Poncet-Legrand, C., Edelmann, A., Putaux, J.-L., Cartalade, D., Sarni-Manchado, P., \& Vernhet, A. (2006). Poly(l-proline) interactions with flavan-3-ols units: Influence of the molecular structure and the polyphenol/protein ratio. Food Hydrocolloids, 20(5), 687-697.

Poncet-Legrand, C., Gautier, C., Cheynier, V., \& Imberty, A. (2007). Interactions between flavan-3-ols and poly(l-proline) studied by isothermal titration calorimetry: effect of the tannin structure. Journal of Agricultural and Food Chemistry, 55(22), 9235-9240.

Prigent, S. V. E., Gruppen, H., Visser, A. J. W. G., van Koningsveld, G. A., de Jong, G. A. H., \& Voragen, A. G. J. (2003). Effects of non-covalent interactions with 5-O-Caffeoylquinic acid (Chlorogenic acid) on the heat denaturation and solubility of globular proteins. Journal of Agricultural and Food Chemistry, 51(17), 5088-5095.

Prigent, S. V. E., Voragen, A. G. J., van Koningsveld, G. A., Baron, A. Renard, C. M. G. C., \& Gruppen, H. (2009). Interactions between globular proteins and procyanidins of different degrees of polymerization. Journal of Dairy Science, 92(12), 5843-5853.

Rawel, H. M., Meidtner, K., \& Kroll, J. (2005). Binding of selected phenolic compounds to proteins. Journal of Agricultural and Food Chemistry, 53(10), 4228-4235.

Renard, C. M. G. C., Dupont, N., \& Guillermin, P. (2007). Concentrations and characteristics of procyanidins and other phenolics in apples during fruit growth. Phytochemistry, 68(8), 1128-1138.

Rinaldi, A., Jourdes, M., Teissedre, P. L., \& Moio, L. (2014). A preliminary characterization of aglianico (Vitis vinifera L. cv.) grape proanthocyanidins and evaluation of their reactivity towards salivary proteins. Food Chemistry, 164, 142-149.

Robbins, R. J., Leonczak, J., Johnson, J. C., Li, J., Kwik-Uribe, C., Prior, R. L., et al. (2009). Method performance and multi-laboratory assessment of a normal phase high pressure liquid chromatography-fluorescence detection method for the quantitation of flavanols and procyanidins in cocoa and chocolate containing samples. Journal of Chromatography A, 1216(24), 4831-4840.

Sanoner, P., Guyot, S., Marnet, N., Molle, D., \& Drilleau, J.-F. (1999). Polyphenol profiles of French cider apple varieties (Malus domestica sp.). Journal of Agricultural and Food Chemistry, 47(12), 4847-4853.

Sun, B., de Sá, M., Leandro, C., Caldeira, I., Duarte, F. L., \& Spranger, I. (2013). Reactivity of polymeric proanthocyanidins toward salivary proteins and their contribution to young red wine astringency. Journal of Agricultural and Food Chemistry, 61(4), 939-946.

Watrelot, A. A., Le Bourvellec, C., Imberty, A., \& Renard, C. M. G. C. (2013). Interactions between pectic compounds and procyanidins are influenced by methylation degree and chain length. Biomacromolecules, 14, 709-718.

Whitesides, G. M., \& Krishnamurthy, V. M. (2005). Designing ligands to bind proteins. Quarterly Reviews of Biophysics, 38(04), 385-395.

Williamson, M. P. (1994). The structure and function of proline-rich regions in proteins. Biochemical Journal, 297(Pt 2), 249-260. 